\title{
Toimintaympäristö muuttuu - miten vastata muutoksiin
}

\author{
Matti Ryhänen ${ }^{1)}$, Margit Närvä ${ }^{1)}$ ja Timo Sipiläinen ${ }^{2)}$
}

${ }^{1)}$ Seinäjoen ammattikorkeakoulu, Maa- ja metsätalouden yksikkö, Ilmajoentie 525, 60800 Ilmajoki, etunimi.sukunimi@seamk.fi

${ }^{2)}$ Helsingin yliopisto ja MTT Taloustutkimus, Taloustieteen laitos, PL 27, 00014 Helsingin yliopisto, timo.sipilainen@helsinki.fi

\section{Tiivistelmä}

Maitoalalla toimintaympäristön muutosten ennakointi on tärkeää, jotta kyetään tekemään oikeita päätöksiä tulevaisuutta varten. Maidontuotannon toimintaympäristön muutosten ennakointi, tulevaisuuden visiointi, nykyisen toiminnan parantaminen ja tuotantoprosessien kehittäminen ovat keskeisiä yritystoiminnan osa-alueita. Tämän tutkimuksen tarkoituksena oli tuottaa maitotilojen kehittämistä tukevaa ennakointitietoa toimintaympäristöstä ja siinä tapahtuvista muutoksista sekä löytää keinoja, miten toimialalla voidaan vastata näihin muutoksiin.

Tutkimusaineisto hankittiin järjestämällä kuusi työpajaa. Niihin osallistui asiantuntijoita tutkimuksesta, yritysmaailmasta, maataloushallinnosta, neuvonnasta, koulutuksesta ja maidontuottajista. Työpajoihin osallistui kerrallaan 15-18 asiantuntijaa. Teemoina olivat markkinat, rahoitus, maatalouspolitiikka, laatujohtaminen, tuotannon kehittäminen ja rakennuttaminen. Työpajoista saatiin kattava ja monipuolinen aineisto maitotoimialan analyysiä varten. Analyysin pohjalta haettiin ratkaisumalleja ja toimintamuotoja Etelä-Pohjanmaan ja Keski-Suomen maidontuotannon kehittämiseksi.

Toimialan SWOT-analyysillä tuotettiin tietoa maidontuotannon toimintaympäristöstä ja arvioitiin maitotilojen toimintaedellytyksiä tulevaisuudessa. Tulosten mukaan pääosalta maitotiloista strategia puuttuu ja tavoitteet ovat osin epäselviä. Maitotilat ovat keskimäärin heikosti kannattavia ja yrityskooltaan pieniä. Maidontuotannon kehittäminen ja yrityskoon kasvattaminen edellyttävät lisäresurssien hankintaa. Yrittäjän on hankittava uutta osaamista, uuteen tuotantoteknologiaan on investoitava ja tuotantoprosesseja on kehitettävä sekä uusia toimintamalleja on rakennettava. Tällä hetkellä yrittäjien osaaminen on painottunut tuotantoon ja tekniikkaan. Jatkossa on panostettava aiempaa enemmän liikkeenjohdollisen osaamisen kehittämiseen. Maitotilan investoinnit vaativat suurta pääomapanostusta, joten rahoitusmahdollisuuksista on huolehdittava. Toimintaympäristön ollessa jatkuvassa muutoksessa yrittäjän on löydettävä omat vahvuutensa ja toimittava parhaalla mahdollisella tavalla selvitäkseen menneillään olevasta rakennemuutoksesta. Uudet yhteistyömuodot mahdollistavat yrittäjän erikoistumisen aiempaa enemmän yrityksensä johtamiseen ja maidontuotantoon. Perinteisellä osaamistasolla ja yksin toimien edellytykset pärjätä tulevaisuuden toimintaympäristössä heikkenevät koko ajan.

Maidontuottajat voivat hyödyntää saatuja tuloksia mm. oman liiketoimintansa suunnittelussa ja yritystoiminnan kehittämisessä, kuten esimerkiksi yritystason SWOT-analyysien laadinnassa, tuotantoprosessien hallinnassa, tuotannon tehostamisessa ja lopulta kannattavuuden parantamisessa.

Asiasanat: maidontuotanto, strategia, SWOT-analyysi, toimintaympäristö, työpaja 


\section{Johdanto}

Maitoalan toimintaympäristössä tapahtuu jatkuvasti muutoksia, joista maidontuottajan ja koko maitoketjun tulee olla tietoinen omaa toimintaansa kehittäessään. Maitomarkkinoilla kilpailu kovenee koko ajan. Maidon ja rehujen hintojen vaihtelut, politiikkamuutokset ja vuonna 2015 näkyvissä oleva maitokiintiöjärjestelmän purku asettavat maitoalalle suuria haasteita. Maidontuottajan ja koko maitoketjun on varauduttava kilpailun kovenemiseen ja toimintaympäristön muutoksiin, mikä pakottaa lopulta koko maitoketjun hakemaan uusia ratkaisuja.

Samanaikaisesti kun toimintaympäristössä tapahtuu isoja muutoksia, on maitoalalla menossa rakennemuutos, jossa maitotilojen määrän vähenee ja jäljelle jäävien koko kasvaa. Toimintaympäristön muutokset vaikuttavat maidontuottajan valintoihin, mikä näkyy mm. maidon tuotantomäärien ja määrien muutosten eroina artikla 141 ja 142 toteuttamisalueilla. Artiklan 142 soveltamisalueella maitomäärät ovat pysyneet lähes samana tilakoon ja keskituotoksen kasvun ansiosta. Maitomäärän väheneminen on ollut huomattavaa artiklan 141 soveltamisalueella. Meijeriteollisuuden näkökulmasta tarkasteltuna maitoa tuotetaan välillä liikaa ja välillä liian vähän. Maitomäärän sopeuttaminen kysyntää vastaavasti on haasteellista. Maidontuottajat eivät kykene reagoimaan nopeisiin markkinatilanteen vaihteluihin, koska lehmien tuotosta ei kyetä säätelemään teollisuusmaisesti.

Yksittäisen maidontuottajan näkökulmasta katsottuna tärkeimpiä haasteita ovat kannattavuus ja yrittäjän jaksaminen. Maitotilojen kannattavuuteen vaikuttavat yrittäjän toimenpiteet ja toimintaympäristössä tapahtuvat muutokset. (Närvä ym. 2008, 5, 15.) Maitotilojen kehittämisessä ja yritystoiminnan kannattavuuden parantamisessa on oleellista tietää, miten toimintaympäristön muutokset vaikuttavat omaan yritykseen ja sen mahdollisuuteen pärjätä uudessa toimintaympäristössä. Maidontuottajan on muodostettava omalle yritykselle sopiva strategia ja toteutettava se. Käytännössä se merkitsee maidontuottajan tietoista keskeisten tavoitteiden ja toiminnan suuntaviivojen valintaa, asioiden laittamista tärkeysjärjestykseen ja valintojen toteuttamista. Tutkimustieto ja käytännön kokemus osoittavat, että menestymisen taustalla on strategia (mm. Olson 2004, 21-65; Santalainen 2006, 22).

Strategian suunnittelu voidaan jakaa kolmeen eri tasoon: yritystason strategia, liiketoimintatason strategia ja toimintotason strategia (mm. Hofer ja Schendel 1978, 27-29; Bamberger \& Bonacker 1994, 33). Yrityksen tasolla strategia vastaa pääasiassa kysymykseen, missä liiketoiminnoissa ollaan mukana. Toiminnan laajuus ja resurssien jakaminen eri liiketoiminnoille ovat tällöin strategian pääkomponentteja. Liiketoimintatasolla strategia määrittelee, miten saavutetaan kilpailuetua tietyssä liiketoiminnossa tai tuote- tai markkinasegmentillä. Lisäksi strategia integroi eri toimintojen strategioita kilpailustrategiaan sopivaksi kokonaisuudeksi. Toimintotason strategia keskittyy maksimoimaan resurssien tuottavuutta ja löytämään synergiaa toimintojen sisällä. Maitotilan strategian muodostamisessa tarvitaan kykyä ennakoida tulevaisuuden muutoksia, jotta yrityskokonaisuuden johtaminen, eläinten hoito ja ruokinta sekä muut tilan toiminnot saadaan ohjattua tulevaisuuden odotuksia vastaaviksi ja tukemaan strategian toteuttamista. Lisäksi kehittävällä maitotilalla on ratkaistava, miten tilan prosessit järjestetään tulevaisuuden toimintaympäristöä varten.

Kun päätetään, mikä yrityksen strategian pitäisi olla, täytyy tunnistaa ympäristön uhat ja mahdollisuudet sekä arvioida vaihtoehtoihin sisältyviä riskejä. On myös arvioitava yrityksen vahvuudet ja heikkoudet havaittujen mahdollisuuksien toteuttamisessa ja riskeistä selviytymisessä. Etsitään siis yhteensopivuutta niiden välillä, mitä yritys pystyy tekemään (vahvuudet ja heikkoudet) ja mitä se voisi tehdä (mahdollisuudet ja uhat). (mm. Andrews 1971.) Tämä strategian muodostamisprosessin osa, jossa etsitään ympäristön mahdollisuuksia ja uhkia sekä yrityksen heikkouksia ja vahvuuksia, on tänä päivänä laajasti tunnettu SWOT-analyysina.

Maitotilan toimintaympäristössä tapahtuu muutoksia, joihin yksittäisen maidontuottajan pitää varautua ja tarvittaessa muuttaa toimintaansa. Maatilan toimintaympäristö koostuu Olsonin (2004) mukaan neljästä pääelementistä: resurssit, markkinat, instituutiot ja teknologia. Saatavilla olevat resurssit määrittelevät, millainen tila on. Resurssit sisältävät mm. maan, työvoiman, pääoman, johtamistaidon, rahoituksen saatavuuden sekä myös ilmaston ja sään. Yrittäjän oma kyvykkyys on kriittinen resurssi. Tietolähteiden hyödyntämisen merkitys kasvaa ja ne on nähtävä myös resurssina. Yrittäjän päätöksiin vaikuttavat markkinoilla tapahtuvat muutokset. Markkinat määrittävät tuotteiden ja panosten hinnat. Instituutiot, kuten hallinto ja pankit vaikuttavat maidontuottajan päätöksiin. Tuotannonohjaus, kuten tuet ja kiintiöpolitiikka, ovat asioita, jotka yksittäinen maidontuottaja joutuu huomioimaan valintoja tehdessään. Teknologialla tarkoitetaan tässä yhteydessä fyysisiä, mekaanisia ja biologisia prosesseja ja tekniikoita sekä liikkeenjohdollisia tietoja ja prosesseja. Menneet, nykyiset ja tulevat 
teknologiavalinnat vaikuttavat tuottavuuteen ja kannattavuuteen. Tuottavuuden kasvu edellyttää uuden teknologian hyödyntämistä ja tilarakenteen kehittämistä. Luonnonoloista aiheutuu tuottavuuseroja maiden välille (Sipiläinen ym. 2008). Maidontuottajan täytyy tarkastella toimintaympäristöä kokonaisuutena. Toimintaympäristössä tapahtuvat muutokset luovat mahdollisuuksia ja uhkia.

Tämän tutkimuksen tarkoituksena oli tuottaa maitotilojen kehittämistä tukevaa ennakointitietoa toimintaympäristöstä ja siinä tapahtuvista muutoksista sekä löytää keinoja, miten toimialalla voidaan vastata näihin muutoksiin.

\section{Aineisto ja menetelmät}

Ennakointitietoa tuotettiin kuudessa eri työpajassa. Työpajojen teemoina olivat markkinat, rahoitus, maatalouspolitiikka, laatujohtaminen, tuotannon kehittäminen ja rakennuttaminen. Jokainen teema analysoitiin aluksi omana kokonaisuutenaan. Tämän jälkeen työpajoissa tuotetun aineiston ja niiden pohjalta tehtyjen mahdollisuuksien ja uhkien analyysin sekä vahvuuksien ja heikkouksien analyysin tulosten perusteella laadittiin Etelä-Pohjanmaan ja Keski-Suomen aluetta varten maitotoimialan SWOT-analyysi. Analyysin tuloksia voidaan hyödyntää maitotiloilla yritystason analyyseissä ja yrittäjien päätöksenteon tukena.

Aluksi muodostettiin "ennakointiryhmä", joka valmisteli työpajojen ohjelmat ja teemat. Ennakointiryhmä kutsui työpajoihin osallistujat, jotka olivat ulkopuolisia asiantuntijoita. Kuhunkin työpajaan osallistui kerrallaan 15-18 asiantuntijaosanottajaa. Heidät jaettiin ennakointiryhmän toimesta etukäteen kolmeen ryhmään siten, että jokaisessa ryhmässä oli mahdollisimman tasaisesti yritysten, maidontuottajien, maataloushallinnon, neuvonnan, tutkimuksen ja koulutuksen edustajia. Yhden työpajatyöskentelyn kesto oli noin 4 tuntia. Työpajatyöskentelyä veti ennakointiryhmän puheenjohtaja. Työskentelyä valvoivat tutkimushankkeeseen osallistuvien tahojen edustajat. Työpajatyöskentelyt etenivät ennakointiryhmän etukäteen laatimien työjärjestysten mukaisesti. (ks. Ryhänen ym. 2011, 11; 77-88.)

Työpajatyössä hyödynnettiin ulkopuolisten asiantuntijoiden osaamista ja panosta. Jokainen asiantuntija kirjasi aluksi jokaisesta kolmesta teemasta henkilökohtaisen näkemyksensä paperille. Sen jälkeen aloitettiin työskentely pienryhmissä. Osallistujat paneutuivat työhönsä intensiivisesti. Ryhmätyöskentelyn aikana jokainen ryhmä kokosi yhdestä teemasta tulokset teemataululle ja kahden muun teeman osalta paperille. Seuraavaksi työpajaryhmät kiersivät kahdella muulla teematauluilla ja täydensivät paperilta teematauluille ryhmiensä aikaan saamat tulokset. Lopuksi teematauluille kootut tiedot, ajatukset ja ideat käytiin kaikkien työpajaan osallistuneiden kanssa yhdessä läpi. Tällä tavoin varmistettiin, että ryhmätyöskentelyn tulokset ymmärrettiin oikein. Tässä vaiheessa kaikilla osallistujilla oli mahdollisuus kommentointiin ja tarpeellisiin lisäyksiin.

Työpajatyöskentelyn jälkeen laadittiin PowerPoint -ohjelmapohjaiset yhteenvedot työpajatyöskentelyn tuloksista, ajatuksista ja ideoista. Yhteenvetoihin lisättiin myös hankkeeseen osallistuvien tahojen (SeAMK, JAMK, MTT, ProAgria Etelä-Pohjanmaa, Maitosuomi ja TTS) edustajien tekemiä havaintoja työpajoissa käydyistä keskusteluista, millä parannettiin kokonaiskuvan muodostamista. Työpajoihin osallistuneille asiantuntijoille toimitettiin yhteenvedot nopeasti, jotta he voivat antaa tarvittaessa palautetta. Yhteenvedoilla tieto saatettiin nopeasti hyödyttämään käytännön maidontuotannon kehittämistyötä. Lopullinen tutkimusaineisto koostui teematauluille kootuista tiedoista, PowerPoint -yhteenvedoista ja työskentelyn aikana tehdyistä havainnoista ja muistiinpanoista.

\section{Tulokset ja tulosten tarkastelu}

\section{Toimintaympäristö muuttuu}

Globalisaatio muuttaa toimintaympäristöä. EU:n maatalouspolitiikan uudistuksen myötä markkinaohjautuvuus kasvaa. Tuontipaineiden kasvu, vientikilpailun koveneminen ja kuluttajakäyttäytymisen muutokset tuovat haasteita maitoalalle. Markkinaohjautuvuuden kasvu lisää hintavaihteluita ja niistä tulee yhä epäsäännöllisempiä. Ne aiheuttavat epävarmuutta markkinoille, mikä vaikeuttaa maidontuottajien päätöksentekoa ja lisää riskiä. Haasteet maitomarkkinoilla siten lisääntyvät.

Tulevaisuudessa on tarvetta ennakoivalle tiedolle, sillä nykyään maidontuottajalla ei ole käytössään luotettavaa markkinatietoa. Luotettava aineisto ja analyysit ovat edellytys sille, että optimaaliset ratkaisut ovat mahdollisia. Työpajoissa päädyttiin yksimielisesti näkemykseen, että maidontuottajan päätöksenteon tueksi tarvitaan uutta tietoa, jotta hän voi varautua ja reagoida toimintaympäristön muu- 
toksiin aiempaa paremmin. Maidontuottajien on tärkeää saada tuotteiden ja tuotantopanosten hinnoista ja määristä luotettavaa markkinatietoa, minkä puute on tällä hetkellä ongelma, niin valtakunnan kuin tarkastellun alueenkin tasolla. Kansainvälisen ja kotimaisen markkina-aineiston kokoaminen, tuottaminen ja analysointi ovat tulevaisuudessa tarpeen. Toteuttaminen edellyttää laajaa yhteistyötä, jotta tieto saadaan luotua ja siirrettyä ymmärrettävässä muodossa loppukäyttäjille asti. Maidontuottajan on lisäksi tärkeä ymmärtää kuluttajien odotuksia, sillä he ostokäyttäytymisellään lopulta ratkaisevat maitotuotteiden menekin. Sillä on taas vaikutus maidon hintaan ja maidontuottajan ratkaisuihin.

Vaikka markkinaohjautuvuus kasvaa, maidontuotanto ei jää täysin markkinoiden varaan. EU:n ja yhteiskunnan tasapainottavia toimia maitomarkkinoilla tarvitaan edelleen $\mathrm{mm}$. tasoittamaan luonnonoloista aiheutuvia tuottavuuseroja. Maitoalan toimintaedellytysten turvaamiseen on panostettava, sillä EU-maista Suomelle maidontuotanto on suhteellisesti tärkein maataloustuotannon ala. EU-tasolla on tarpeen hakea keinoja maitomarkkinoiden stabilointiin. Viranomaismääräysten tulee olla ajantasaisia ja maidontuotannon toimintaympäristöön myös käytännössä soveltuvia.

Suomessa hintatuki on sallittu maidontuotannossa, mutta kansainvälisesti siitä pyritään eroon, mikä lisää maatalouspolitiikan haasteellisuutta. Suomi saa jatkossakin tukea C-alueella maidontuotantoa artiklan 142 mukaisesti. Maidon hintatuki ei saa tällä alueella kasvattaa tuotantoa, joten artikla sisältää alueellisen tuotantorajoitteen. Suomen maitoalalla on yhteistoimin huolehdittava C-alueelle määrätyn tuotantorajoitteen pitävyydestä.

Markkinakilpailu kuuluu yhteiskuntaamme ja siten myös maitoalalle. Markkinoilta puuttuu yhteiskuntavastuu, joten yhteiskunnan tehtävänä on laatia markkinoille pelisäännöt. Siksi maatalouspolitiikkaa tarvitaan. Kyse ei ole yrittäjyyden rajoittamisesta, vaan sääntöjen luonnista maataloustuotantoon ja elintarvikemarkkinoille, jotta markkinoilla toimitaan vastuullisesti. Sääntöjen asettaminen on sitä tärkeämpää, mitä suuremmat vaikutukset ja seuraukset toiminnalla ovat. Ruoan tuottaminen ja elintarvikemarkkinoiden toimivuus vaikuttavat ihmisten jokapäiväiseen elämään. Siksi jokainen maa haluaa turvata ruoantuotantoedellytykset ja ruoan saatavuuden $\mathrm{mm}$. kompensoimalla luonnonolojen vuoksi heikentynyttä kilpailukykyä. Pelisääntöjen merkitys korostuu myös silloin, kun kilpailu ei toimi. Esimerkkinä mainittakoon kilpailutilanne, jossa jollakin taholla on ylivoimainen neuvotteluasema suhteessa muihin.

\section{Keinoja vastata toimintaympäristön muutoksiin}

Yleisesti todetusta maitoalan kehittämistarpeesta huolimatta pääosalta maitotiloista strategia puuttuu ja tavoitteet ovat epäselviä. Yrittämishalua on, mutta ilman strategiaa toiminnan pitkäjänteisyys kärsii, kun tavoitteet ja toimet vaihtelevat liikaa. Maidontuotannon kehittäminen ja yrityskoon kasvattaminen edellyttävät lisäresurssien hankintaa ja yleensä suurta pääomapanosta. Siten tuotantoa kehittävien maidontuottajien rahoitusmahdollisuuksista on huolehdittava.

Yritystoiminnan kehittäminen edellyttää myös uuden osaamisen hankintaa. Osaaminen on perinteisesti ollut tuotanto- ja tekniikkakeskeistä. Tulevaisuudessa on panostettava aiempaa enemmän liikkeenjohdolliseen osaamiseen. Liiketoimintaosaaminen on keskeisessä asemassa tulevaisuuden maitotilaa johdettaessa. Liiketoimintaosaamisen varmistaminen monipuolisella ja ajantasaisella koulutuksella on kovenevassa kilpailussa menestymisen edellytys. Markkinaohjautuvuuden kasvu muuttaa maitotilojen taloudellista toimintaympäristöä. Se asettaa uusiutumishaasteen myös koulutukselle ja neuvonnalle, sillä ne ovat perinteisesti painottaneet luonnontieteellisistä lähtökohdista lähtevää koulutusta ja neuvontaa.

Toimintaympäristön ollessa jatkuvassa muutoksessa maidontuottajan on löydettävä omat vahvuutensa, toimittava parhaalla mahdollisella tavalla ja selvittävä menossa olevasta rakennemuutoksesta. Kannattavan toiminnan perustana ovat tehokkuus, kilpailukyky sekä kustannusjohtajuus. Erilaistamisstrategia ei sovellu maidontuotantoon, sillä meijerille toimitettavaa raaka-ainetta ei ole mahdollista erilaistaa, koska meijeri tarvitsee tuotantoprosesseihinsa tasalaatuista raaka-ainetta. Laatutason ja hinnoitteluperusteet määrittää meijeri. Hyvät kannattavuusedellytykset on ehto sille, että nuoret kiinnostuvat alasta. Muutoin alalle ei saada motivoituneita ja osaavia yrittäjiä.

Maidontuotannossa, kuten muussakin yritystoiminnassa, laatu on ymmärrettävä kokonaisvaltaisesti. Prosessien organisointi ja kehittäminen ovat tärkeä osa laadun hallintaa, jotta laadukas lopputuote voidaan tuottaa kustannustehokkaasti. Laatu ja kustannukset eivät ole keskenään ristiriidassa, sillä laadukkaiden prosessien ansiosta toiminta tehostuu ja yksikkökustannukset alenevat. Maidontuot- 
tajat tarvitsevat erityisesti johtamistaitoja ja taloudellista osaamista sekä niiden rinnalle riittävässä määrin tuotantomenetelmien ja -prosessien hallintaa.

Maitotiloilla on panostettava yhteistyön lisäämiseen ja syventämiseen. Uudet yhteistyömuodot ovat tarpeen, jotta maidontuottaja voi erikoistua aiempaa enemmän yrityksensä johtamiseen ja maidontuotantoon. Investointien suunnittelu ja toteutus on nähtävä tulevaisuudessa prosessina, johon maidontuottajat voivat parhaiten varautua suunnittelemalla niitä yhteistuumin toisten viljelijöiden kanssa. Kotieläin- ja kasvinviljelytilojen yhteistyön edistäminen parantaa tavoitteen toteuttamista. Joillakin alueilla yhteistyön esteeksi voi muodostua, etteivät maatalousyrittäjät usko yhteistyöhön, vaikka se on selkeä mahdollisuus parantaa tuotannon kannattavuusedellytyksiä. Perinteisellä osaamistasolla ja yksin toimien ei kuitenkaan pärjätä tulevaisuudessa.

Kuluttajien tarpeet muuttuvat ajan myötä. Maitoalalla tarvitaan joustavuutta ja muutosherkkyyttä, jotta muutoksiin kyetään vastaamaan. Kuluttajien tarpeiden ennakointi ja niiden tunnistaminen on tärkeää menestyksen kannalta. Maitoalan on oltava valmiina reagoimaan muutoksiin, jotta se kykenee vastaamaan kuluttajien tarpeisiin ja kykenee pitämään kotimaiset tuotteet houkuttelevina. Se edellyttää osaamisen vahvistamista entisestään koko maitoketjussa. Suomalaiset kuluttajat pitävät kotimaisia maitotuotteita korkealaatuisina ja kotimaista maitoalaa luotettavana toimijana. Luotettavuus nykyisten ruokakriisien koettelemassa maailmassa on valttikortti, jonka merkitys on korostumassa.

\section{Toimialan SWOT-analyysin tuloksien hyödyntäminen tilatasolla}

Toimialan SWOT-analyysin tulokset auttavat maidontuottajaa hahmottamaan toimintaympäristön muutosten vaikutuksia yrityksensä toimintaedellytyksiin. Toimiala-analyysien pohjalta maidontuottaja voi pohtia kilpailuasemaansa ja sitä, mitkä tekijät erottavat tulevaisuuden menestyjät ja mitkä ovat keskeiset menestystekijät. Hyödyntäessään toimiala-analyysien tuloksia maidontuottaja saa käyttöönsä laaja-alaisesti pohdittua ja analysoitua tietoa. Se on myös tehokas tapa saada tietoa siitä, miten kilpailukykyä on tarpeen ja mahdollista parantaa ja mihin toimiin maitotilalla on ryhdyttävä, jotta maidontuottaja kykenee varmistamaan kuuluvansa tulevaisuuden menestyjien joukkoon.

Toimialan SWOT-analyysin tuloksia voi tulkita yhteistyössä muiden maidontuottajien kanssa. Vertailua maidontuottajien kesken voi tehdä $\mathrm{mm}$. benchmarkkauksella. Tukitiimien ja tilarenkaiden avulla sekä tilojen välisellä yhteistyöllä saadaan käyttöön vertailuaineistoja. Maidontuottajat voivat muodostaa klubeja, jotka tuottavat aineistot sovitusti. Vertaamalla oman tilan suorituksia parhaisiin tuloksiin ja pohtimalla, miten ne voidaan saavuttaa ja mahdollisesti ylittää, voidaan kehittää tilan eri osa-alueita. Klubilaiset hyötyvät yhteistyöstä, sillä kukin heistä saa uutta tietoa siitä, millä osa-alueilla on tarve ja mahdollisuus suorituskyvyn parantamiseen. Kilpailijat jäävät tältä osin tätä tietoa vaille.

Maidontuottajan on asetettava selkeät tavoitteet ja saatava strategiansa kuntoon. Strategia on perustettava sille, missä yritys on vahva ja kilpailukykyinen, sillä heikkoudet eivät voi olla menestyksen lähde. Strategian pohjalta laaditaan liiketoimintamalli eli käytännönläheinen toimintasuunnitelma strategian toteuttamiseksi. Maidontuottajan osaaminen, verkostot, luotettavat ja osaavat yhteistyökumppanit ja työntekijät voivat muodostaa ydinkompetenssin, jonka varaan menestys on mahdollista rakentaa. Osaaminen ja taidot ovat vaikeasti kopioitavia menestystekijöitä. Toimialan analyysien perusteella keskeisiä maitotilan menestykseen vaikuttavia tekijöitä ovat:

- tieto ja osaaminen sekä maidontuottajan kyky ja halu soveltaa uutta tietoa,

- maidontuottajan liikkeenjohdolliset taidot,

- maidontuottajan yhteistyökyky ja -halu,

- maidontuottajan joustavuus reagoida muutokseen,

- maidontuottajan valmius kehittää tuotantoa ja ottaa uutta teknologiaa käyttöön,

- maidontuottajan kyky ja halu uudistaa ja kehittää tuotantoprosesseja ja

- olemassa olevat ja hankittavissa olevat resurssit.

\section{Johtopäätökset}

Maitoalalla toimintaympäristön muutosten ennakointi on tärkeää. Konkreettisiin toimenpiteisiin tulisi ryhtyä mahdollisimman nopeasti, jotta maidontuottajien päätöksenteon tueksi saadaan uutta ja luotettavaa markkinatietoa, minkä puute on tällä hetkellä selkeä ongelma yritystoimintaa kehitettäessä. Kansainvälisen ja kotimaisen markkina-aineiston kokoaminen, tuottaminen ja analysointi ovat tarpeen.

Toimialan SWOT-analyysillä on mahdollista tuottaa hyödyllistä tietoa toimintaympäristöstä. Maidontuottaja voi hyödyntää tätä tietoa yrityksensä kehittämisessä, johtamisessa ja päätöksenteossa. 
Maitoalalla tarvitaan uutta osaamista, uuteen tuotantoteknologiaan on investoitava ja tuotantoprosesseja on kehitettävä sekä uusia toimintamalleja on rakennettava. Toteutus edellyttää sekä aineettoman eli osaamisen että aineellisen pääoman hankintaa. Tuotanto- ja tekniikkakeskeinen osaaminen ei yksin enää riitä. Maidontuottajien on panostettava yhä enemmän liiketoimintaosaamiseen. Osaamistarpeiden muutos vaikuttaa myös koulutuskysyntään.

Muuttuvassa toimintaympäristössä maidontuottajan on löydettävä omat vahvuutensa. Maitotiloilla yhteistyön lisääminen ja syventäminen luovat uusia mahdollisuuksia. Uudet yhteistyömuodot ovat tarpeen, jotta maidontuottaja voi erikoistua aiempaa enemmän yrityksensä johtamiseen ja maidontuotantoon. Esimerkiksi investointien suunnittelu ja toteutus voidaan tulevaisuudessa järjestää projektina, jonka maidontuottajat voivat toteuttaa uudella tapaa. He voivat käyttää ulkopuolista asiantuntijuutta (esim. tyyppinavettahanke) ja kilpailuttaa tavarantoimittajia yhdessä toisten maidontuottajien kanssa. Kotieläin- ja kasvinviljelytilojen yhteistyö voi tehostaa resurssien käyttöä. Lisäksi maidontuottajien ja sidosryhmien tulisi tehdä nykyistä enemmän yhteistyötä. Mahdollisuuksia on, kun niitä vaan halutaan hyödyntää ja osataan käyttää.

Kuluttajien tarpeet muuttuvat ajan myötä. Maitoalalla tarvitaan joustavuutta ja muutosherkkyyttä, jotta maitotuotteiden kysyntämuutoksiin kyetään reagoimaan riittävän nopeasti. Siten kuluttajien ostokäyttäytymisen ennakointi on tarpeen. Toimintaympäristön muuttuessa maitoalan on kyettävä pitämään kotimaiset tuotteet houkuttelevina. Se edellyttää osaamisen vahvistamista entisestään. Luotettavuus nykyisten ruokakriisien koettelemassa maailmassa on valttikortti, jonka merkitys todennäköisesti korostuu tulevaisuudessa.

\section{Kirjallisuus}

Andrews, K. R. 1971. The Concept of Corporate Strategy. Homewood, IL. DoW Jones -Irwin. Bamberger, I. \& Bonacker, R. 1994. Strategies of small and medium-sized enterprises and their measurement. Teoksessa: Bamberger, I. (toim.) Product/Market Strategies of Small and Mediumsized Enterprises. Avebury, Aldershot, 28-85.

Hofer C.W. \& Schendel D. 1978. Strategy Formulation: Analytical Concepts. West Publishing Co, St. Paul, Minnesota.

Närvä, M., Ryhänen, M., Veikkola, E. \& Vuorenmaa, T. 2008. Esiselvitys maidontuotannon kehittämiskohteista. Loppuraportti. Seinäjoen ammattikorkeakoulun julkaisuja, B 36.

Olson, K. D. 2004. Farm Management: Principles and Strategies. Iowa State Press.

Ryhänen, M. \& Nissinen, K. (toim.) 2011. Kilpailukykyä maidontuotantoon: Toimintaympäristön tarkastelu ja ennakointi. Seinäjoen ammattikorkeakoulun julkaisusarja A. Tutkimuksia 8.

Santalainen, T. 2006. Strateginen ajattelu. Gummerus Kirjapaino OY, Jyväskylä. Talentum.

Sipiläinen, T., Kuosmanen, T. \& Kumbhakar, S. C. 2008. Measuring productivity differentials - An application to milk production in Nordic countries. Julkaisussa: XIIth Congress of the European Association of Agricultural Economists "People, Food and Environments: Global Trends and European Strategies". 